\title{
Accounting for land use, biodiversity and ecosystem services in life cycle assessment: impacts of breakfast cereals
}

DOI:

10.1016/j.scitotenv.2018.07.088

\section{Document Version}

Accepted author manuscript

Link to publication record in Manchester Research Explorer

Citation for published version (APA):

Jeswani, H. K., Hellweg, S., \& Azapagic, A. (2018). Accounting for land use, biodiversity and ecosystem services in life cycle assessment: impacts of breakfast cereals. Science of the Total Environment, 645, 51-59.

https://doi.org/10.1016/j.scitotenv.2018.07.088

Published in:

Science of the Total Environment

\section{Citing this paper}

Please note that where the full-text provided on Manchester Research Explorer is the Author Accepted Manuscript or Proof version this may differ from the final Published version. If citing, it is advised that you check and use the publisher's definitive version.

\section{General rights}

Copyright and moral rights for the publications made accessible in the Research Explorer are retained by the authors and/or other copyright owners and it is a condition of accessing publications that users recognise and abide by the legal requirements associated with these rights.

\section{Takedown policy}

If you believe that this document breaches copyright please refer to the University of Manchester's Takedown Procedures [http://man.ac.uk/04Y6Bo] or contact uml.scholarlycommunications@manchester.ac.uk providing relevant details, so we can investigate your claim.

\section{OPEN ACCESS}




\title{
Accounting for land use, biodiversity and ecosystem services in life cycle assessment: impacts of breakfast cereals
}

\author{
Harish Kumar Jeswani ${ }^{1 *}$, Stefanie Hellweg ${ }^{2}$ and Adisa Azapagic ${ }^{1}$ \\ ${ }^{1}$ Sustainable Industrial Systems, School of Chemical Engineering and Analytical Science, The \\ University of Manchester, Manchester, UK \\ ${ }^{2}$ Institute of Environmental Engineering, ETH Zurich, 8093 Zurich, Switzerland
}

*Corresponding author. Email address: harish.jeswani@manchester.ac.uk

\begin{abstract}
This study considers the life cycle impacts of land use on biodiversity and ecosystem services associated with the production of a ubiquitous food type: breakfast cereals. For biodiversity, the impacts on five taxonomic groups have been assessed: mammals, birds, vascular plants, amphibians and reptiles. For ecosystem services, the potential loss in the following ecosystem services of soil has been considered: biotic production, erosion resistance, groundwater regeneration, infiltration and physicochemical filtration. The findings indicate that the main hotspot for the biodiversity loss is cocoa cultivation for all taxonomic groups, with a contribution of $27-67 \%$. Cocoa is also a major contributor (35\%) to the loss of biotic production, while rice is the largest contributor to erosion (34\%), reduction in groundwater replenishment (43\%) and physiochemical filtration (23\%). Corn is the main cause of the infiltration reduction, accounting for $44 \%$ of the impact. Unlike the biodiversity impacts, which are almost entirely caused by agricultural activities, non-agricultural land use occurring in other life cycle stages (transport, packaging and manufacturing), has significant contribution to the reductions in groundwater replenishment and infiltration. The impacts on ecosystem services are almost entirely driven by land occupation, while the biodiversity impacts are caused by both land use change and occupation. The identification of cocoa as the main hotspot is unexpected as it is used only in very small quantities (less than $5 \%$ by mass) in breakfast cereals. Its high contribution to the impacts is partly due to the land use change in the ecoregion of the Eastern Guinean forests, which are home to a relatively large number of endemic species. The paper also discusses the limitations of the impact assessment methods for evaluating the biodiversity and ecosystem services and highlights the need for further development of indicators and methods to assess the land use impacts in life cycle assessment.
\end{abstract}

Keywords: breakfast cereals; biodiversity; land use; ecosystem services; life cycle assessment

\section{Nomenclature}

$\begin{array}{ll}\text { BPLP } & \text { Biotic production loss potential } \\ \text { BPP } & \text { Biotic production potential } \\ \text { CFs } & \text { Characterisation factors } \\ \text { CRP } & \text { Climate regulation potential } \\ \text { EP } & \text { Erosion potential } \\ \text { FWRP } & \text { Freshwater regulation potential } \\ \text { GRRP } & \text { Groundwater regeneration reduction potential } \\ \text { IRP } & \text { Infiltration reduction potential } \\ \text { LCA } & \text { Life cycle assessment } \\ \text { LCIA } & \text { Life cycle impact assessment } \\ \text { LUC } & \text { Land use change } \\ \text { LULUC } & \text { Land use and land-use change } \\ \text { PFRP } & \text { Physicochemical filtration reduction potential } \\ \text { SAR } & \text { Species-area relationship } \\ \text { SHSM } & \text { Species habitat suitability model } \\ \text { WPP } & \text { Water purification potential }\end{array}$




\section{Introduction}

Land use by agri-food systems can have significant impacts on biodiversity as well as the structure and functions of ecosystems. According to the Millennium Ecosystem Assessment report (WRI, 2005), habitat destruction caused by land use and land-use change (LULUC) is one of the five main drivers of terrestrial biodiversity loss, together with climate change, invasive alien species, overexploitation of resources and pollution. Two main impact pathways for LULUC have been proposed by UNEP-SETAC (Koellner et al., 2013): i) biodiversity damage potential; and ii) ecosystem services damage potential. Biodiversity is a complex and heterogeneous concept, involving multiple levels of life (e.g. genes, species, ecosystems), various biological attributes (e.g. composition, structure, function) and a multitude of spatial and temporal dynamics (Curran et al., 2011). The term ecosystem services conceptualises how ecological processes support human well-being (Othoniel et al., 2016). The services provided by ecosystems include provision of food, fibre, biomass and freshwater as well as regulation of carbon sequestration, soil degradation or erosion and water purification (WRI, 2005).

The importance of assessing the land use impacts on biodiversity and ecosystem services through life cycle assessment (LCA) is widely recognised; however, the task remains difficult. A number of studies have attempted to develop biodiversity indicators and spatial models to quantify them (for a review, see Curran et al., 2016). The most notable life cycle impact assessment (LCIA) models for biodiversity have been developed using species-area relationship (SAR) model of biodiversity loss (de Baan et al., 2013a,b; Chaudhary et al., 2015) and species habitat suitability model (SHSM). The latter, proposed by de Baan et al. (2015), provides characterisation factors (CFs) for mammals based on their conservation status and global rarity but, due to a very large data demand of this approach, global coverage was not achieved and taxonomic coverage was restricted to mammals. By contrast, the CFs provided by the same authors in an earlier study (de Baan et al., 2013a, b) quantify regional and endemic species loss in all global ecoregions for mammals, birds, vascular plants, amphibians and reptiles. Chaudhary et al. (2015) further developed this approach by including more data and weighting regional species loss with a spatiallyresolved factor that combines the rarity and threat level of species (based on Verones et al., 2013), thus developing an indicator of global species extinctions. The study also provided CFs for land occupation and land use change for 804 ecoregions and six land use classes: intensive forestry, extensive forestry, annual crops, permanent crops, pasture and urban land. The UNEP-SETAC Life Cycle Initiative recommended this approach as the best practice for identification of hotspots for land-use biodiversity impacts in LCA (UNEP-SETAC, 2016).

For ecosystem services, several indicators and their characterisation factors have been proposed in various studies; for a review, see Othoniel et al. (2016) and Vidal Legaz et al. (2017). For example, the indicator 'climate regulation potential' (CRP), proposed by MüllerWenk and Brandão (2010), considers $\mathrm{CO}_{2}$ transfers between vegetation/soil and the atmosphere in the course of terrestrial release and re-storage of carbon due to land use. Brandão and Milà i Canals (2013) provided a characterisation model for impacts of land use on biotic production potential (BPP). The model uses soil organic carbon as an indicator of soil quality, as a proxy indicator for the biotic production capacity of the soil. Saad et al. (2013) proposed CFs for three major ecological functions: erosion potential (EP), freshwater regulation potential (FWRP) and water purification potential (WPP). These indicators have been further developed in the LANCA ${ }^{\circ}$ (LANd use indicator value Calculation tool (Bos et al., 2016). Further discussion of these indicators is provided in the next section.

A few studies have assessed impacts of food products on biodiversity and ecosystem services using some of the above mentioned methods. These include margarine production in the UK and Germany (Milà i Canals et al., 2013) as well as milk and pork in Sweden (Nordborg et al., 2017). Both studies used the aforementioned UNEP-SETAC impact pathways for LULUC (Koellner et al. 2013) and assessed six mid-point categories for ecosystem services: CRP, BPP, FWRP, EP and WPP through infiltration and 
physicochemical filtration. For the margarine study, biodiversity damage potential (BDP) was considered using the approach suggested by de Baan et al. (2013a). In addition, some studies have also assessed land-use impacts of individual crops from particular countries using different methods. For instance, de Baan et al. (2015) assessed impacts of tea, coffee, and tobacco in East Africa using the SAR approach and SHSM. Chaudhary et al. (2016) applied their own biodiversity impact assessment method to global agriculture, pasture and forestry. A global analysis of biodiversity loss by IRP (2017) found that about $10 \%$ of global species were lost because of agricultural crop production, grazing of pasture and wood extraction.

This study focuses on breakfast cereals which represent an integral part of diet in many countries (CEEREAL, 2015). As their production is heavily reliant on land use, the effects on biodiversity and ecosystem services are highly relevant. While the life cycle environmental impacts of breakfast cereals have been reported previously (Jeswani et al., 2015), their influence on biodiversity and ecosystem services remains unknown, thus warranting further study. Recently developed LCIA methods have been applied for these purposes, as detailed in the next section.

\section{Methods}

\subsection{Goal and the scope of the study}

The main goal of the study is to quantify the impact of land use on biodiversity and ecosystem services associated with the production of breakfast cereals. The products considered are ready-to-eat breakfast cereals and snacks manufactured by Kellogg Europe. This is one of the leading producers of breakfast cereals in Europe with a market share of over 35\% (CEEREAL, 2011; Kellogg, 2013). The functional unit is defined as the 'annual production $(388,000$ tonnes) of ready-to-eat breakfast cereal products'. As indicated in Figure 1, the scope of the study is from 'cradle to grave', including:

- agricultural production of cereal grains and other ingredients;

- processing of ingredients, such as corn, wheat, rice, sugar, cocoa, fruits and nuts, to produce different breakfast cereals;

- production of packaging materials and packaging;

- transport of ingredients, packaging materials, products and waste along the life cycle; and

- management of waste in different life cycle stages.

Consumption of cereals is excluded in the base case but it is considered in an additional analysis, assuming the use of milk.

\subsection{Inventory for land occupation and land use change}

The LCIA methods for biodiversity and ecosystem services require identification and quantification of land occupation and land use change (LUC) in a spatially differentiated format. The data on ingredients used in the breakfast cereals and their source countries have been obtained from the manufacturer (Jeswani et al., 2015); for details, see Table S1 in the Supplementary Information (SI). The total area of land occupation in the agricultural stage for each ingredient has been quantified using country specific crop yield data from the Food and Agriculture Organisation (FAO) database (FAOSTAT, 2017). Five-year averages have been used to smooth out yearly variations in the yield. Land occupation by these crops $\left(\mathrm{m}^{2}\right.$ year/kilogram) is obtained as the inverse of the yield. All crops are assumed to require the use of land for one whole year as the per methodology in the World Food LCA Database (Nemecek et al., 2014). This assumption may overestimate land use area for some regions where double cropping is practiced; however, this only affects a very small amount of ingredients considered in this study. The expected ecoregions for each ingredient have been determined using the country specific production maps from USDA (2017). The latter also provides the state or region specific production data for each crop in a given country. These 
values have been used to estimate the land use in each ecoregion in that country for a particular crop (Table 1).

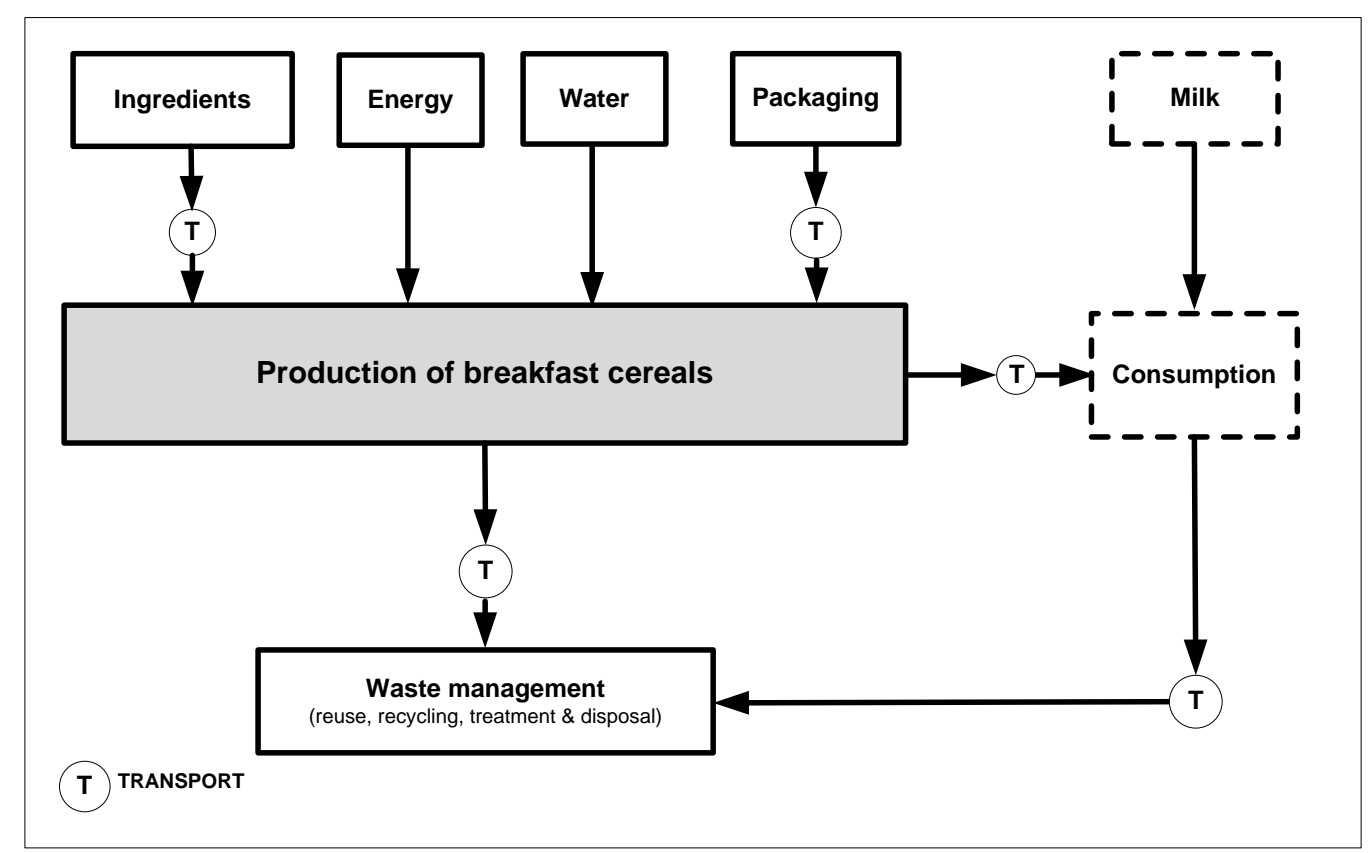

Figure 1 Scope of the study and system boundaries (adapted from Jeswani et al. (2015)) [Consumption of cereals with milk is excluded from the main study but is considered in an additional analysis.]

As shown in Table 1, the top five ingredients with the highest land occupation are corn $(0.52$ $\mathrm{m}^{2}$-year/kg breakfast cereals), rice $\left(0.5 \mathrm{~m}^{2}\right)$, wheat $\left(0.44 \mathrm{~m}^{2}\right)$, cocoa $\left(0.43 \mathrm{~m}^{2}\right)$ and sugar $(0.2$ $\left.\mathrm{m}^{2}\right)$. Corn is imported from Argentina and rice is procured from Italy, Spain, Thailand and Egypt. Wheat and its derivatives are sourced from the UK, Spain and the USA. Cocoa is produced in Côte d'Ivoire while sugar is imported from France, Germany as well as African, Caribbean and Pacific countries. Palm oil, which is used in very small quantities (Table S1), is largely imported from Papua New Guinea, Malaysia and Indonesia (AHDB, 2018). Land occupation for other production stages, i.e. manufacturing, packaging, transport and waste disposal, has been assigned to the most likely country of occurrence. The breakfast cereals are packaged in high density polyethylene bags and carton boxes, which are then packed into larger corrugated-board boxes (see Table S2 in the SI). The data for the background processes have been sourced from the Ecoinvent database (Ecoinvent, 2016).

LUC has been calculated using the approach in the World Food LCA Database (Nemecek et al., 2014). Firstly, in order to determine whether a crop grown in a specific country is potentially associated with any LUC, the FAO database (FAOSTAT, 2017) has been used to analyse the increase in crop area and agricultural land in the country in the last 20 years. This analysis showed that the production of two ingredients involves LUC: cocoa and palm oil. The average crop area for cocoa in Côte d'Ivoire has grown by $42 \%$ in the period of 1992 2011. Similarly, the crop area for palm oil in Papua New Guinea and Malaysia has almost doubled, while for Indonesia it has increased by five times in the same period (FAOSTAT, 2017). Since there has been a significant loss in forest cover during this period in Côte d'Ivoire (CILSS, 2016) and Southeast Asia (Vijay et al., 2016), it has been assumed that all of the LUC estimated in Table 1 (4\% per year for Indonesia, 2.6\% for Papua New Guinea, 2.4\% for Malaysia and $1.5 \%$ for Cote d'Ivoire) represents transformation from forest to permanent crops.

Given that the UK is the major market for the breakfast cereals in Europe (Statista, 2017), the consumption of cereals is assumed there. Hence, the inventory data for milk production in the UK have been considered, noting that these data will vary between countries. The land use values associated with the production of milk in Table 2 have been estimated based on 
the typical feed intake for the medium yielding dairy cow (The Scottish Government, 2010). In the UK, the majority of dairy cattle graze during the summer period and are housed in the winter time where they are fed with silage, hay and concentrates. Soya meal is imported from Argentina and Brazil, sunflower meal from Spain and all other feed components are produced locally. LUC associated with the production of soy meal in Argentina and Brazil has also been estimated using data from FAOSTAT (2017) as per the World Food LCA Database (Nemecek et al., 2014) mentioned above.

\section{Table 1 Land use data for production of breakfast cereals}

\begin{tabular}{|c|c|c|c|c|c|c|}
\hline Ingredient & $\begin{array}{l}\text { Land use } \\
\text { type }\end{array}$ & Country & $\begin{array}{l}\text { Land use } \\
\left(\mathrm{m}^{2}-\mathrm{yr} / \mathrm{kg}\right. \\
\text { ingredient }^{\mathrm{a}}\end{array}$ & $\begin{array}{l}\text { Land use } \\
\left(\mathrm{m}^{2}-\mathrm{yr} / \mathrm{kg}\right. \\
\text { breakfast } \\
\text { cereals) }\end{array}$ & $\begin{array}{l}\text { Land use } \\
\text { change } \\
\text { ( } \mathrm{m}^{2} / \mathrm{kg} \\
\text { breakfast } \\
\text { cereals) }\end{array}$ & Ecoregion ID $^{b}$ \\
\hline Corn & $\begin{array}{l}\text { Annual } \\
\text { crop }\end{array}$ & Argentina & 1.48 & 0.52 & - & $\begin{array}{l}\text { NT0210 (23\%), NT0801 } \\
(28 \%) \& \text { NT0803 (49\%) }\end{array}$ \\
\hline \multirow[t]{4}{*}{ Rice } & Annual & Italy & 1.56 & 0.33 & - & PA0432 \\
\hline & crop & Spain & 1.35 & 0.11 & - & $\begin{array}{l}\text { PA1209 (66\%), PA1215 } \\
(16 \%) \& \text { PA1221 (18\%) }\end{array}$ \\
\hline & & Egypt & 1.04 & 0.03 & - & PA0904 \\
\hline & & Thailand & 3.37 & 0.03 & - & $\begin{array}{l}\text { IM0107 (14\%), IM0139 } \\
(12 \%), \text { IM0163 (3\%) \& } \\
\text { IM0202 (72\%) }\end{array}$ \\
\hline \multirow[t]{3}{*}{ Wheat } & Annual & UK & 1.29 & 0.28 & - & PA0409 \\
\hline & crop & Spain & 3.12 & 0.13 & - & $\begin{array}{l}\text { PA1209 (50\%), PA1216 } \\
(25 \%) \& \text { PA1221 }(25 \%)\end{array}$ \\
\hline & & USA & 3.39 & 0.03 & - & $\begin{array}{l}\text { NA0803 (20\%), NA0810 } \\
(11 \%), \text { NA0811 (33\%), } \\
\text { NA0815 (20\%), NA0813(8\%) } \\
\text { \& NA1309 (9\%) }\end{array}$ \\
\hline \multirow[t]{3}{*}{ Sugar } & $\begin{array}{l}\text { Annual } \\
\text { crop }\end{array}$ & Germany & 0.75 & 0.08 & - & $\begin{array}{l}\text { PA0445 (60\%) \& PA0402 } \\
(40 \%)\end{array}$ \\
\hline & & France & 0.60 & 0.05 & - & PA0402 \\
\hline & & $\begin{array}{l}\text { Brazil, } \\
\text { Caribbean } \\
\text { \& Pacific } \\
\text { states }\end{array}$ & 1 & 0.07 & - & $\begin{array}{l}\text { NT0131 (5\%), NT0150 (10\%), } \\
\text { NT0154 (10\%), NT0218 (5\%), } \\
\text { NT0704 (40\%), NT1315 } \\
(10 \%), \text { IM0165 (5\%), IM0202 } \\
(5 \%), \text { OC0105 (5\%) \& } \\
\text { OC0201 (5\%) }\end{array}$ \\
\hline \multirow[t]{3}{*}{ Palm oil } & $\begin{array}{l}\text { Permanent } \\
\text { crop }\end{array}$ & $\begin{array}{l}\text { Papua } \\
\text { New } \\
\text { Guinea }\end{array}$ & 2.54 & 0.015 & 0.0004 & $\begin{array}{l}\text { AA0111 (70\%), AA0120 } \\
(15 \%), \text { AA0125 (8\%) \& } \\
\text { AA0115 (7\%) }\end{array}$ \\
\hline & & Malaysia & 2.31 & 0.008 & 0.0002 & $\begin{array}{l}\text { IM0102 (50\%) \& IM0146 } \\
(50 \%)\end{array}$ \\
\hline & & Indonesia & 2.7 & 0.004 & 0.00017 & $\begin{array}{l}\text { IM0158 (40\%) IM0160 (40\%) } \\
\text { \& IM0102 (20\%) }\end{array}$ \\
\hline $\begin{array}{l}\text { Maize germ } \\
\text { oil }\end{array}$ & $\begin{array}{l}\text { Annual } \\
\text { crop }\end{array}$ & Belgium & 3.7 & 0.02 & & PA0402 \\
\hline Sunflower oil & $\begin{array}{l}\text { Annual } \\
\text { crop }\end{array}$ & UK & 10.2 & 0.04 & & PA0409 \\
\hline Cocoa & $\begin{array}{l}\text { Permanent } \\
\text { crop }\end{array}$ & $\begin{array}{l}\text { Côte } \\
\text { d'Ivoire }\end{array}$ & 16.4 & 0.43 & 0.0063 & AT0111 \\
\hline Oat & $\begin{array}{l}\text { Annual } \\
\text { crop }\end{array}$ & Germany & 2.25 & 0.07 & - & PA0402 \\
\hline \multirow[t]{3}{*}{ Barley } & Annual & UK & 1.73 & 0.01 & & PA0409 \\
\hline & crop & Spain & 3.26 & 0.01 & - & PA1209 \\
\hline & & Germany & 1.68 & 0.002 & - & $\begin{array}{l}\text { PA0402 (50\%) \& PA0445 } \\
(50 \%)\end{array}$ \\
\hline \multirow{2}{*}{$\begin{array}{l}\text { Dairy } \\
\text { products (milk } \\
\text { powder, } \\
\text { condensed } \\
\text { milk) }\end{array}$} & Pasture & Europe & 6.5 & 0.09 & - & $\begin{array}{l}\text { PA0409 (60\%), PA0402 } \\
(19 \%) \& \text { PA1209 (21\%) }\end{array}$ \\
\hline & $\begin{array}{l}\text { Annual } \\
\text { crop }\end{array}$ & Europe & 4.2 & 0.06 & - & $\begin{array}{l}\text { PA0409 (60\%) PA0402 (19\%) } \\
\text { \& PA1209 (21\%) }\end{array}$ \\
\hline $\begin{array}{l}\text { Fruits and } \\
\text { nuts }\end{array}$ & $\begin{array}{l}\text { Permanent } \\
\text { crop }\end{array}$ & Various & 3.3 & 0.12 & - & $\begin{array}{l}\text { PA0404 (2\%), PA0412 (2\%), } \\
\text { PA1213 (1\%), PA1214 (1\%) } \\
\text { \& NA0801 (94\%) }\end{array}$ \\
\hline
\end{tabular}




\begin{tabular}{|c|c|c|c|c|c|c|}
\hline Ingredient & $\begin{array}{l}\text { Land use } \\
\text { type }\end{array}$ & Country & $\begin{array}{l}\text { Land use } \\
\left(\mathrm{m}^{2}-\mathrm{yr} / \mathrm{kg}\right. \\
\text { ingredient }^{\mathrm{a}}\end{array}$ & $\begin{array}{c}\text { Land use } \\
\text { (m²-yr/kg } \\
\text { breakfast } \\
\text { cereals) }\end{array}$ & $\begin{array}{l}\text { Land use } \\
\text { change } \\
\text { ( } \mathrm{m}^{2} / \mathrm{kg} \\
\text { breakfast } \\
\text { cereals) }\end{array}$ & Ecoregion ID \\
\hline $\begin{array}{l}\text { Other } \\
\text { ingredients \& } \\
\text { background } \\
\text { processes }\end{array}$ & Various & Global & NA & 0.10 & - & Various \\
\hline Manufacturing & Urban & $\begin{array}{l}\text { UK, Spain } \\
\text { \& } \\
\text { Germany }\end{array}$ & NA & 0.015 & - & $\begin{array}{l}\text { PA0409 (60\%), PA0402 } \\
(19 \%) \& \text { PA1209 }(21 \%)\end{array}$ \\
\hline Transport & Urban & $\begin{array}{l}\text { UK, Spain } \\
\& \\
\text { Germany }\end{array}$ & NA & 0.023 & - & $\begin{array}{l}\text { PA0409 (60\%), PA0402 } \\
(19 \%) \& \text { PA1209 }(21 \%)\end{array}$ \\
\hline Packaging & $\begin{array}{l}\text { Managed } \\
\text { forest }\end{array}$ & Austria & NA & 0.154 & - & PA0501 \\
\hline $\begin{array}{l}\text { Process } \\
\text { waste (credits } \\
\text { for animal } \\
\text { feed) }\end{array}$ & $\begin{array}{l}\text { Annual } \\
\text { crop }\end{array}$ & $\begin{array}{l}\text { UK, Spain } \\
\text { \& } \\
\text { Germany }\end{array}$ & NA & -0.05 & - & $\begin{array}{l}\text { PA0409 (60\%), PA0402 } \\
(19 \%) \& \text { PA1209 }(21 \%)\end{array}$ \\
\hline Total & & & & 2.84 & 0.007 & \\
\hline
\end{tabular}

Table 2 Land use data for production of milk

\begin{tabular}{|c|c|c|c|c|c|}
\hline Feed & $\begin{array}{l}\text { Land use } \\
\text { type }\end{array}$ & Country & $\begin{array}{l}\text { Land use } \\
\left(\mathrm{m}^{2}-\mathrm{yr} / \mathrm{l} \text { of }\right. \\
\text { milk) }\end{array}$ & $\begin{array}{l}\text { Land use } \\
\text { change }\left(\mathrm{m}^{2} / \mathrm{l}\right. \\
\text { of milk) }\end{array}$ & Ecoregion ID ${ }^{a}$ \\
\hline Grazing & Pasture & UK & 0.46 & - & PA0409 \\
\hline $\begin{array}{l}\text { Grass silage and } \\
\text { hay }\end{array}$ & Pasture & UK & 0.36 & - & PA0409 \\
\hline Wheat & Annual crop & UK & 0.15 & - & PA0409 \\
\hline Barley & Annual crop & UK & 0.06 & - & PA0409 \\
\hline $\begin{array}{l}\text { Sugar beet \& } \\
\text { molasses }\end{array}$ & Annual crop & UK & 0.01 & - & PA0409 \\
\hline Distillers grains & Annual crop & UK & 0.002 & - & PA0409 \\
\hline Soya meal & Annual crop & $\begin{array}{l}\text { Argentina } \\
\text { and Brazil }\end{array}$ & 0.09 & 0.0024 & $\begin{array}{l}\text { NT0801 (18\%), NT0803 } \\
(25 \%), \text { NT0210 (17\%), } \\
\text { NT0101 (14\%) \& NT0704 } \\
(26 \%)\end{array}$ \\
\hline Rapeseed meal & Annual crop & UK & 0.07 & - & PA0409 \\
\hline $\begin{array}{l}\text { Sunflower meal } \\
\text { Total }\end{array}$ & Annual crop & Spain & $\begin{array}{c}0.01 \\
1.2\end{array}$ & 0.0024 & PA1209 \\
\hline
\end{tabular}

${ }^{\mathrm{a}}$ The codes for different ecoregions are defined in the Supplementary Information (Table S3).

\subsection{Impact assessment methods}

The biodiversity impacts have been assessed using the approach proposed by Chaudhary et al. (2015) and updated by UNEP-SETAC (2016). This method uses the countryside SAR model to predict the absolute loss of species for each of the five taxonomic groups (mammals, birds, vascular plants, amphibians and reptiles) in 804 terrestrial ecoregions. The species loss has then been weighted by the rarity and the average threat level for the species in each ecoregion to obtain an indicator of global, irreversible extinction of species. The method also provides the aggregated CFs for biodiversity, which are calculated as follows: firstly, CFs for each of the five taxonomic groups are divided by the biodiversity threat to their respective species; secondly, the CF values for the four animal groups (mammals, birds, amphibians and reptiles) are averaged and aggregated using equal weighting; and finally, the overall CF is obtained by averaging the CFs for the vascular plants and aggregating with the averaged animal CF using equal weighting (UNEP-SETAC, 2016). 
The impacts on ecosystem services have been assessed using the LANCA v2.0 method (Bos et al., 2016). The method takes into account different farming practices (such as irrigated, non-irrigated, intensive, extensive, etc.) and provides CFs for 58 different land use types and practices. The CFs are provided at a country level. The following five indicators included in LANCA have been estimated:

- biotic production loss potential (BPLP): decrease in ecosystem's ability to produce biomass;

- erosion potential (EP): increase in soil erosion rates due to land use;

- groundwater regeneration reduction potential (GRRP): loss of soil's capacity to replenish groundwater sources;

- infiltration reduction potential (IRP): loss in soil's permeability due to land use; and

- physicochemical filtration reduction potential (PFRP): loss in soil's ability to prevent groundwater contamination due to a reduction in soil's ability to adsorb dissolved substances from the water.

The indicators have been estimated using the CFs in LANCA for relevant countries and land types, as given in Table 1 and Table 2. LCA software GaBi ts V7.3 (Thinkstep, 2016) has been used to model the system and estimate the land use impacts.

\subsection{Uncertainty analysis}

Uncertainty analysis has been carried out to check the robustness of the results against a likely range of variations in both land use inventory and the CFs for biodiversity impacts. Country specific yield data for the respective crops over the five-year period from the FAO database (FAOSTAT, 2017) have been used, considering minimum and maximum values, to characterise the variations in land use values for each ingredient. For the biodiversity CFs, the upper and lower ranges provided by the UNEP-SETAC (2016) have been used. A Monte Carlo simulation with 10,000 iterations has been performed using RiskAMP add-in tool in Excel to generate the probabilistic results.

\section{Results}

The results are first discussed for the production of breakfast cereals excluding their consumption, followed by the impacts when the consumption is included.

\subsection{Impacts of cereals production on biodiversity}

The impacts of breakfast cereals production on biodiversity are given in Figure 2. The highest number of species lost is found for vascular plants, with the annual loss of 1.5 species per year. This is followed by 0.014 lost amphibian species, 0.011 birds, 0.009 mammals and 0.007 reptiles per year. The relatively large number of plant species lost in comparison to the animal species is not surprising as the total number of the former is much higher globally than the number of the respective animal taxa considered here. The aggregated biodiversity loss is estimated at $4 \times 10^{-6} \mathrm{PDF}$ per year.

As also indicated in Figure 2, LUC has higher contribution (40-46\%) to the loss of mammals, birds, amphibians and reptiles than to the loss of vascular plant species (25\%). The LUC impacts are largely related to cocoa cultivation. Its contribution to the total impact on different taxonomic categories and the aggregated loss of biodiversity ranges from $27 \%$ to $67 \%$ (Figure 3 ). In the case of mammals, the other major contributors are rice (10\%), oil (7\%) and corn $(8 \%)$, while for the impact on vascular plants, rice and wheat cultivation contribute $15 \%$ each. Sugar and oil are the other major contributors to the loss of bird species $(12-17 \%)$, amphibians (9-12\%) and reptiles (8-9\%). For the aggregated impact, oil (13\%), rice $(12 \%)$, sugar $(9 \%)$, and wheat $(9 \%)$ are the other main contributors.

Although cocoa is used in small quantities in breakfast cereals $(<5 \%$ by mass), its large impact on biodiversity is due to the following reasons. Firstly, cocoa plants have very low yields and hence high land requirements (see Table 1). Secondly, cocoa plantations are situated in the ecoregion of the Eastern Guinean forests (AT0111) where the biodiversity is 
under a significant threat due to agricultural expansion (IUCN, 2015). Therefore, the CFs for the biodiversity loss due to both land occupation and LUC are rather high for this region (Chaudhary et al., 2015). The impacts of oil on biodiversity are predominantly associated with deforestation caused by the expansion of palm oil plantations in Papua New Guinea, Malaysia and Indonesia.

Figure 2 also shows $90 \%$ confidence intervals represented by the whiskers, suggesting high uncertainty associated with these impacts. This is largely due to the uncertainty in the biodiversity CFs for different species.

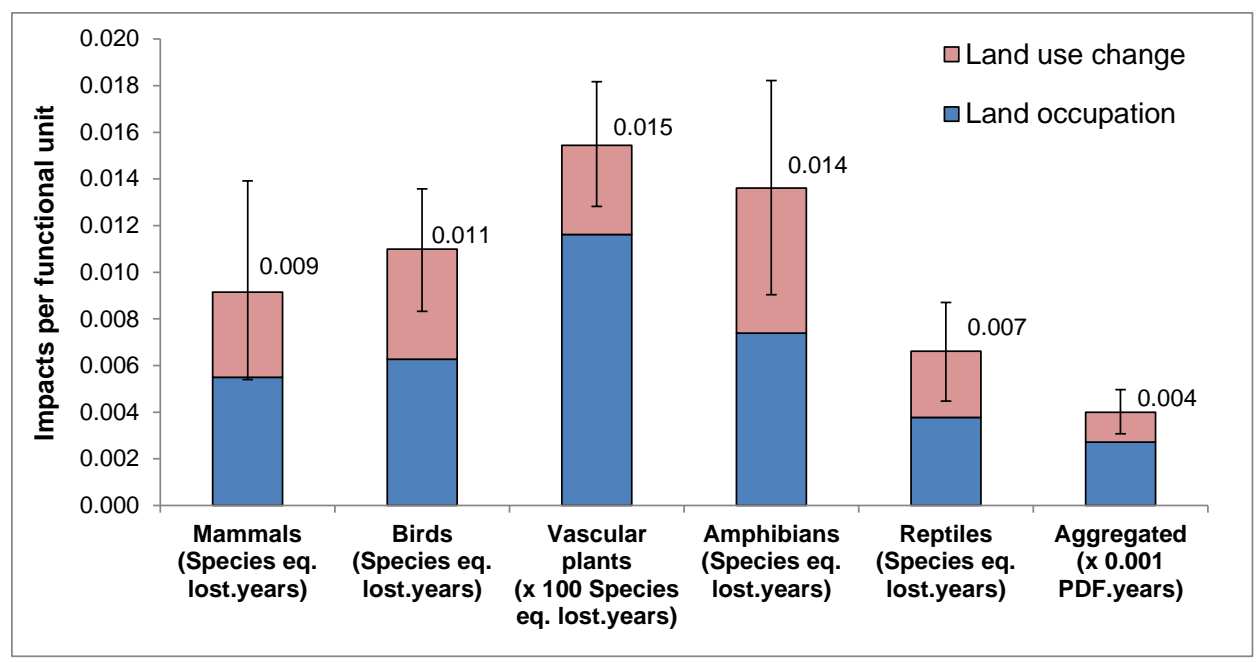

Figure 2 Biodiversity impacts of breakfast cereals

[Functional unit: annual production of breakfast cereals (388,000 tonnes). Some values have been scaled to fit. To obtain the original value, multiply by the factor on the $\mathrm{x}$-axis if shown. The values on top of the graph bars represent the total impact for different species. The whiskers represent the spread between the $5^{\text {th }}$ and $95^{\text {th }}$ percentile ranges. PDF: potentially disappeared fraction.]

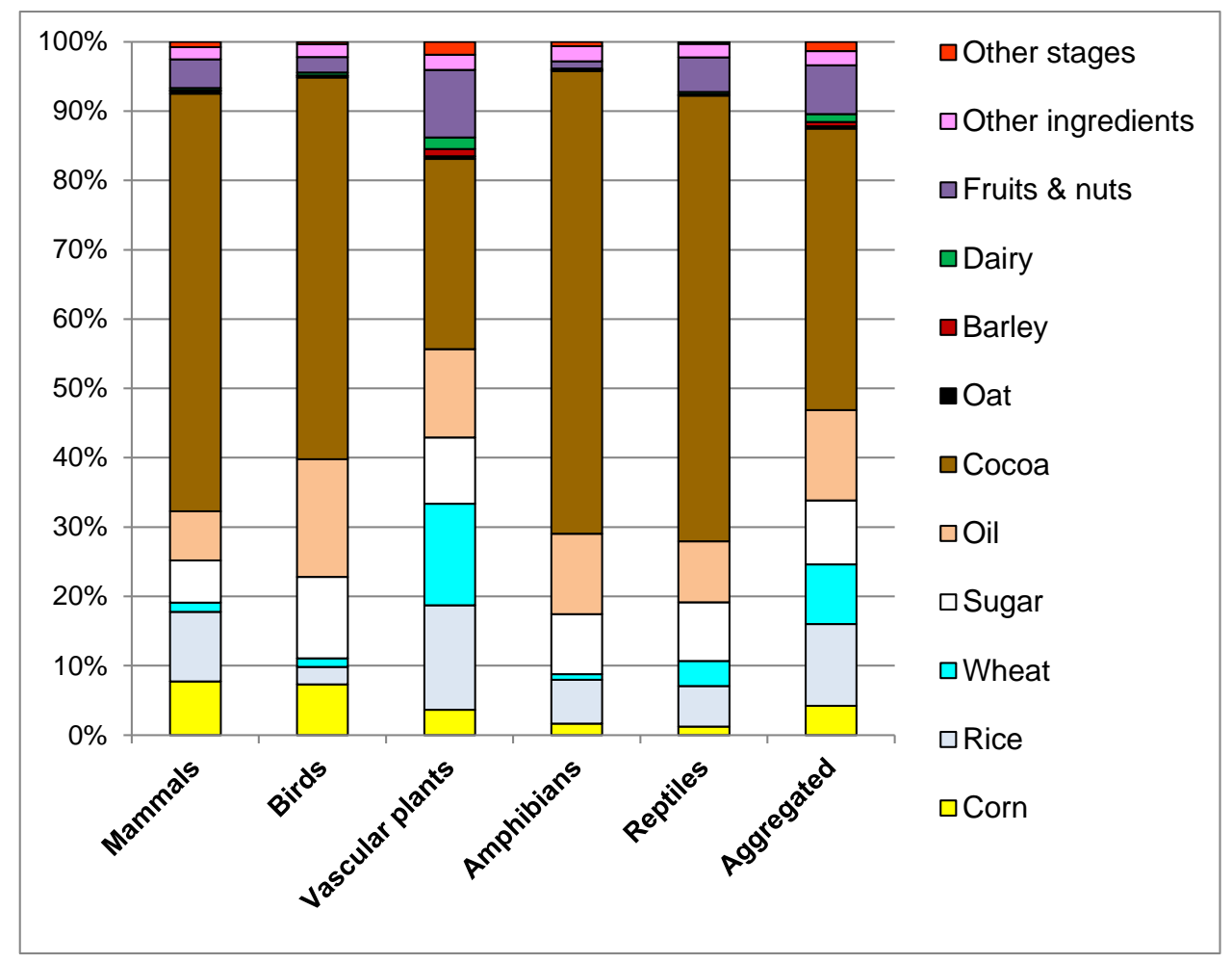

Figure 3 Contribution of the ingredients and other life cycle stages to the biodiversity impacts

[Functional unit: annual production of breakfast cereals (388,000 tonnes). Other stages include manufacturing, packaging and transport.] 


\subsection{Impacts of cereals production on ecosystem services}

The results in Figure 4 indicate that production of breakfast cereals has significant impacts on ecosystem services. For example, for the annual production, there is a loss of $0.53 \mathrm{Mt}$ in biomass production; that is $1.4 \mathrm{~kg}$ for every $\mathrm{kg}$ of breakfast cereals produced. Furthermore, $20 \mathrm{~kg}$ of soil are lost per $\mathrm{kg}$ of cereal products due to erosion, amounting to $7.8 \mathrm{Mt}$ per year. Groundwater regeneration and water infiltration are reduced respectively by 4.1 and 27.9 billion $\mathrm{m}^{3}$ annually, equivalent to $10.5 \mathrm{~m}^{3}$ and $72 \mathrm{~m}^{3}$ per $\mathrm{kg}$ of cereals. The soil's ability to adsorb pollutants from water is also reduced by 43 moles of cations per $\mathrm{kg}$ of products or 16.6 bn moles annually. Unlike biodiversity, all impacts on ecosystem services are almost entirely caused by land occupation as opposed to LUC (Figure 4).

The main contributor to the loss of biomass production is cocoa, followed by rice, wheat and sugar (Figure 5). Rice and cocoa are the also the main hotspots for soil erosion. In the case of groundwater regeneration, rice accounts for $43 \%$ of the impact while for water infiltration, corn is the main hotspot. There is a relatively high contribution from non-agricultural land use occurring in other stages, specifically due to transport, packaging and manufacturing, for both groundwater regeneration and physicochemical filtration. This is due to the sealed surfaces for roads and other infrastructure, which prevent water infiltration into the soil.

\subsection{Impacts from consumption of cereals}

Breakfast cereals are usually eaten with milk. For most types, it is recommended on product packaging that $125 \mathrm{ml}$ of semi-skimmed milk be added per $30 \mathrm{~g}$ serving. Therefore, this section considers the additional impacts on biodiversity and ecosystem services if the consumption with milk is included.

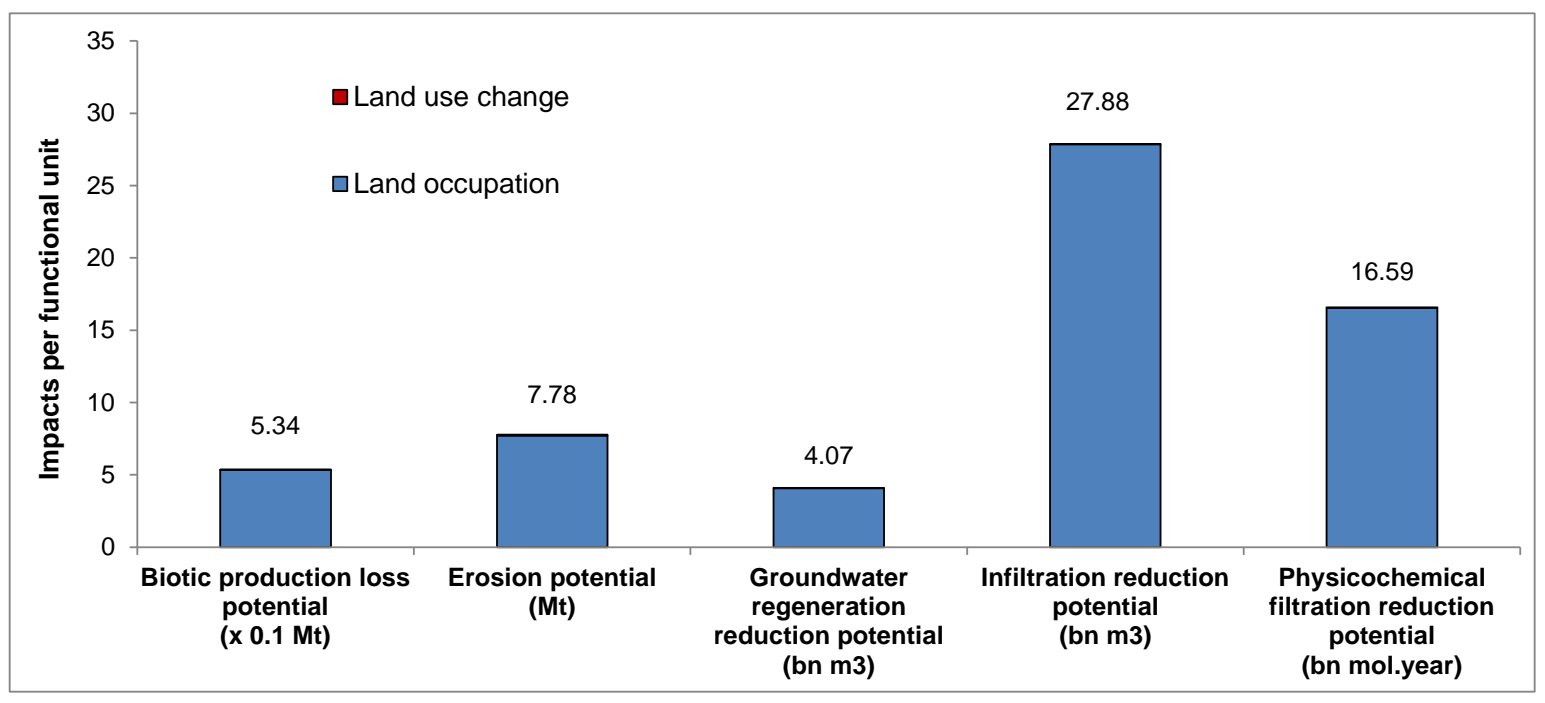

Figure 4 Impacts of breakfast cereals on ecosystem services related to land use

[Functional unit: annual production of breakfast cereals (388,000 tonnes). Some values have been scaled to fit. To obtain the original value, multiply by the factor on the x-axis if shown. bn mol.year: billion moles of cations in a year.] 


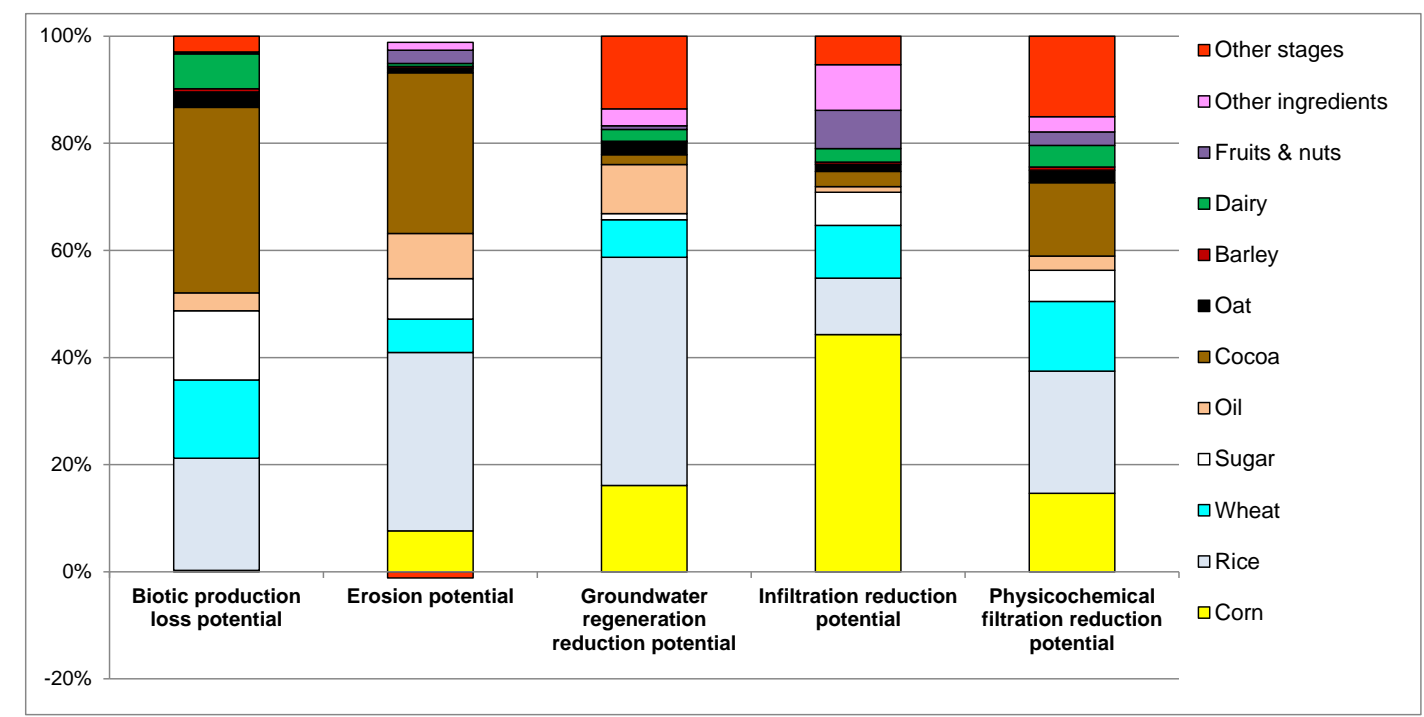

Figure 5 Contribution of ingredients and other life cycle stages to the impacts on ecosystem services

[Functional unit: annual production of breakfast cereals (388,000 tonnes). Other stages include manufacturing, packaging and transport.]

It can be seen in Figure 6 that adding milk to the cereals increases the biodiversity impacts by $7 \%$ (reptiles) to $28 \%$ (birds). The relatively low contribution of milk to the loss of biodiversity can be explained by the fact that milk production occurs in the UK which is not as rich in biodiversity as some of the ecoregions where the key cereal ingredients are produced. There is also a high uncertainty associated with these impacts as shown by the $90 \%$ confidence interval ranges.

On the other hand, milk increases all ecosystem services impacts significantly (Figure 7). The most notable increase is found for the impacts on biomass production and physicochemical filtration, which are 4.7 and 3.4 times worse, respectively, compared to the impacts when the consumption of milk is not considered. The impact on groundwater recharge and infiltration is 2.4 times higher, while the increase in the erosion potential is $31 \%$. This rise in the impacts on the ecosystem services is due to two reasons: 4.2 litres of milk are generally consumed with $1 \mathrm{~kg}$ of breakfast cereals; and a significant land area is needed for the production of feed and fodder for cows (Table 2).

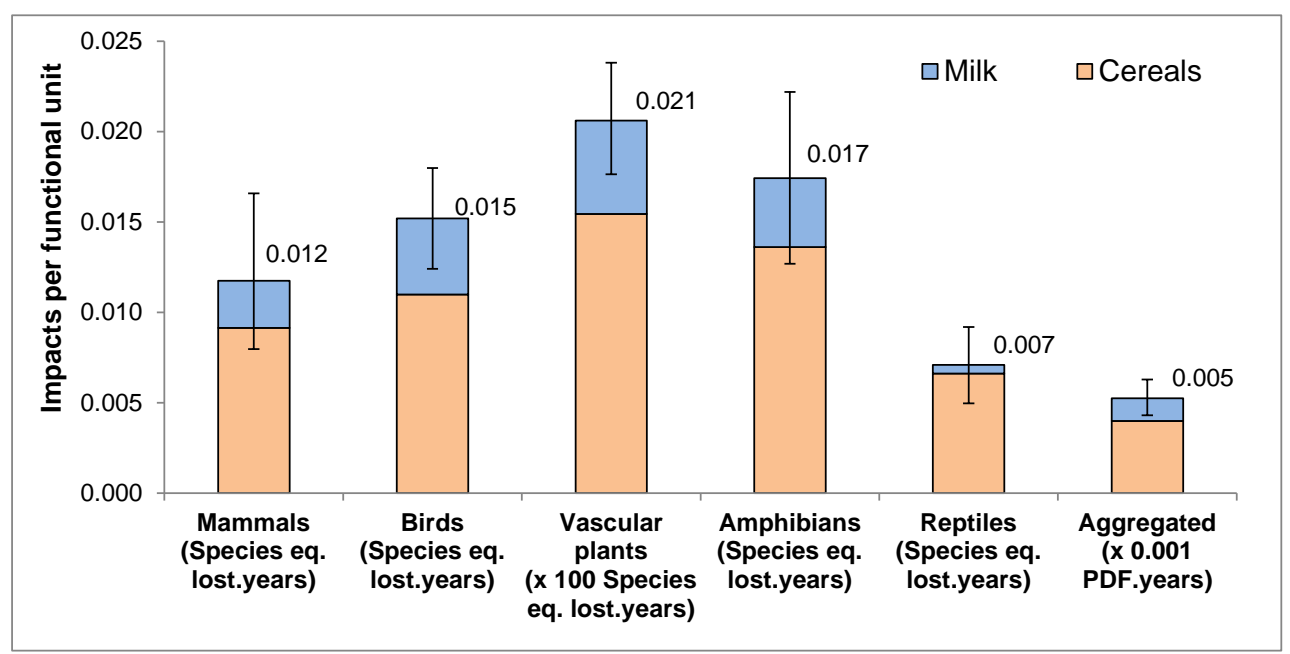

Figure 6 Biodiversity impacts of breakfast cereals including consumption with milk [Functional unit: annual production of breakfast cereals (388,000 tonnes). Some values have been scaled to fit. To obtain the original value, multiply with the factor on the $x$-axis if shown. The values on top of the graph bars represent the total impact for different species. The whiskers represent the spread between the $5^{\text {th }}$ and $95^{\text {th }}$ percentile ranges. PDF: potentially disappeared fraction.] 


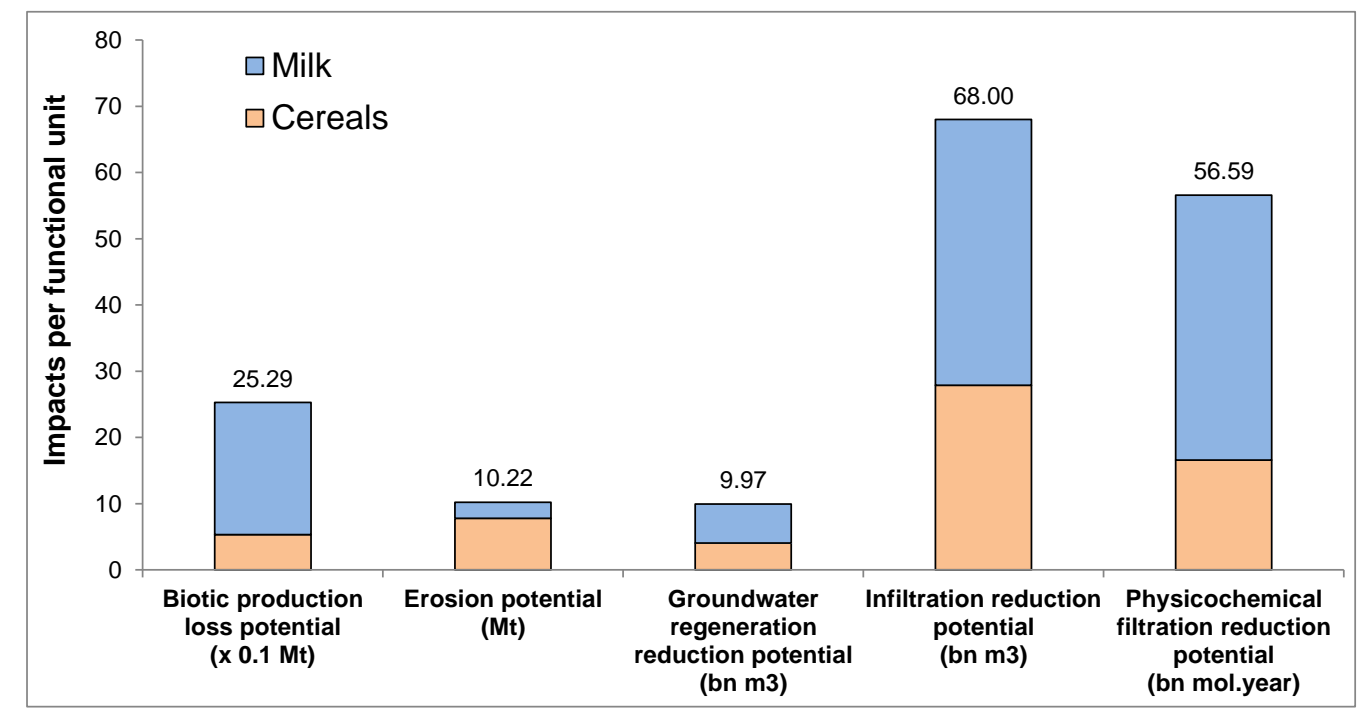

\section{Figure 7 Land use impacts on ecosystem services of breakfast cereals including consumption with milk}

[Functional unit: annual consumption of breakfast cereals with milk (388,000 tonnes). Some values have been scaled to fit. To obtain the original value, multiply with the factor on the $x$-axis if shown. The values on top of the graph bars represent the total impacts.]

\section{Discussion}

Including the potential impacts of land use on biodiversity and ecosystem services in LCA studies of agricultural products is important, but this work highlights several challenges in doing so. With the increasing globalisation, ensuring traceability of supply chains is difficult as many food products incorporate ingredients sourced from multiple locations around the world. Moreover, the assessment of land use impacts in LCA is still in infancy and there is a lack of consensus on which indicators to use and how to estimate them.

This study applied two recently developed methods for land use impacts on biodiversity and ecosystem services. Both methods offer regionalised characterisation factors, though on a different spatial scale, one at an ecoregion level (Chaudhary et al., 2015) and another at a country level (Bos et al., 2016). The ecoregion level has been recommended by UNEPSETAC (2016) as the best practice in LCA. However, although it offers a better spatial resolution than a country-level approach, the uncertainties due to the differences in land use intensities are large, as can be seen in the uncertainty ranges provided in Chaudhary et al. (2015). Some of these uncertainties can be reduced by further distinguishing between the land use types by land management and farming practices, such as intensive, extensive and organic. The potential impacts on ecosystems services are also expected to have high uncertainty but the LANCA method (Bos et al., 2016) does not provide such data to conduct an uncertainty analysis. Although it considers several farming practices, it does not differentiate between conventional and organic agricultural practices. Therefore, further development of these methods and characterisation factor is needed for more accurate assessments of the land use impacts. However, this may increase the demand for data, which may not be readily available.

The method used for assessing biodiversity impacts relies on species loss as an indicator of biodiversity, which has certain limitations (Fleishman, et al., 2006). For example, species richness does not distinguish between small and large populations of species, i.e. their abundance. Also, it is unable to account for biodiversity damages owing to the complex changes in the composition and community structure that can take place following land use change (Medenhall et al., 2012).

Currently, there are several indicators for land use impacts for both biodiversity and ecosystem services. Some of these indicators and models have a low degree of reliability 
due to a weak scientific basis for indicator selection (Nordborg et al., 2017). This also hinders the assessment of land use impacts in LCA studies. Although Chaudhary et al. (2015) provide aggregated CFs for biodiversity loss from land use, such indicator is also needed for ecosystem services. Therefore, the LCA community should strive to develop a transparent and meaningful overall indicator for land use impacts, which decision makers can use to quantify, compare and reduce the land use impacts of their products. Such indicator should ideally include all the relevant indicators for biodiversity and ecosystem functions affected by land use. The other option could be to have an aggregated indicator for ecosystem services similar to that for biodiversity. However, it is important that the aggregation should not be carried out at the cost of reducing transparency. The assessment model would also need validation against real data to improve their reliability.

The expansion and intensification of agriculture in response to the growing demand for food, fibre and fuel represents a serious threat to the biodiversity and ecosystem services which are vital to humans and from which agriculture itself benefits. Therefore, the agricultural sector has to transform to achieve the dual and inter-related goals of food security and environmental protection (FAO, 2016). To do so, the sector has to move away from high inputs and intensive monoculture cropping practices to a more ecosystem-based approaches, with solutions based on the use of local resources. These include use of compost, manure and mulch to improve soil productivity and natural methods to protect pollinators and pest predators (FAO, 2016). It is also paramount that the future expansion of agriculture avoids areas of high conservation value and high carbon stock (Chaplin-Kramer, 2015). Food companies and other influential supply chain actors have a significant role to play in moving towards ecosystem-based agricultural practices by engaging actively with farmers and growers and ensuring that the production of their ingredients is not associated with land use change.

\section{Conclusions}

This study has applied recently developed methods for assessing the impacts of land use on biodiversity and ecosystem services. Production of breakfast cereal products has been used as an illustrative example to test the application of the methods using real data and also identify any challenges and future research needs. For biodiversity, the impacts on five taxonomic groups have been considered: mammals, birds, vascular plants, amphibians and reptiles. The potential loss in the following ecosystem services of soil has been evaluated: biotic production, erosion resistance, groundwater regeneration, infiltration and physicochemical filtration.

The findings indicate that the highest annual species loss occurs for the vascular plants (1.5 species) and the lowest for the reptiles ( 0.007 species). The higher loss of plant species is due to there being many more plant than animal species globally. The main contributor to the biodiversity loss for all taxonomic groups is cocoa cultivation, causing $27-67 \%$ of the impact. This is despite its small amount in breakfast cereals $(<5 \%)$. The high impact from cocoa is due to two factors: the lower yield of cocoa plants (and higher land occupation) and deforestation of the Eastern Guinean forests rich in endemic species.

In relation to the impacts on ecosystem services, the hotspots differ across the impact categories. For example, cocoa is the major contributor to the loss of biotic production, while rice is the largest cause of erosion and the reduction in groundwater replenishment and physiochemical filtration. In the case of infiltration reduction, corn is the main hotspot. Unlike the biodiversity loss, which is almost entirely caused by agricultural activities, non-agricultural land use in other stages (transport, packaging and manufacturing) has higher contribution for some services, such as ground water regeneration and physicochemical filtration. The results also indicate that the impacts on ecosystem services are almost entirely driven by land occupation, while for biodiversity, land use change is also a significant contributor.

Consumption of cereals with milk increases all impacts on ecosystem services significantly. The impact is particularly high for biotic production and reduction in physiochemical filtration, which are four to five times higher compared to the impacts when consumption is not 
considered. On the other hand, the increase in biodiversity loss due to the milk is relatively small, ranging from $7 \%$ for reptiles to $28 \%$ for birds.

The results of the study should be interpreted with caution due to the uncertainties in the methods and additional uncertainties associated with the challenges in applying the methods. Nevertheless, the findings indicate that, besides avoiding agricultural expansion in forests, reductions in the land-use related impacts should focus on ecosystem based agricultural practices, such as crop rotation, intercropping and reduction in agro-chemical inputs. Food companies and other supply chain actors should play a significant role in implementation of these practices by engaging actively with farmers and growers.

The study also highlights the need for further development of indicators and methods to assess the impacts of land use on biodiversity and ecosystem services. Further research is needed to assess the usefulness of the various impact indicators. Development of an overall meaningful and practical indicator for land use impacts would help decision makers to quantify, compare and reduce the land use impacts of their products.

\section{Acknowledgements}

This study was funded by the UK Engineering and Physical Sciences Research Council (EPSRC, Grant no. EP/K011820/1), which is gratefully acknowledged. The authors are also grateful to Dr. Abhishek Chaudhary at the ETH Zurich for discussions on the topic in the early stages of the study.

\section{References}

AHDB (2018) Import \& export data: palm oil, http://cereals-data.ahdb.org.uk/archive/import.asp.

Bos, U., Horn, R., Beck, T., Lindner, J. and Fischer, M. (2016) LANCA: Characterization factors for Life Cycle Impact Assessment, Version 2.0, Stuttgart.

Brandão, M. and i Canals, L.M. (2013) Global characterisation factors to assess land use impacts on biotic production. The International Journal of Life Cycle Assessment 18(6), 1243-1252.

CEEREAL (2011) Promoting breakfast cereals as part of a balanced diet and healthy lifestyle, www.ceereal.eu/documents/2011/DOC ASPE CEEREAL CORPBROCHURE FINAL.pdf.

CEEREAL (2015) About our Industry, http://www.ceereal.eu/about-our-industry.

Chaplin-Kramer, R., Sharp, R.P., Mandle, L., Sim, S., Johnson, J., Butnar, I., Milà i Canals, L., Eichelberger, B.A., Ramler, I., Mueller, C., McLachlan, N., Yousefi, A., King, H. and Kareiva, P.M. (2015) Spatial patterns of agricultural expansion determine impacts on biodiversity and carbon storage. Proceedings of the National Academy of Sciences 112(24), 7402-7407.

Chaudhary, A., Verones, F., de Baan, L. and Hellweg, S. (2015) Quantifying land use impacts on biodiversity: Combining species-area models and vulnerability indicators. Environmental Science \& Technology 49(16), 9987-9995.

Chaudhary, A., Verones, F., de Baan, L., Pfister, S. and Hellweg, S. (2016) Land stress: Potential species loss from land use (global; PSSRg), http://www.lcimpact.eu/downloads/documents/Land stress chapter LCImpact July 17 2016.pdf.

Chaudhary, A., Pfister S., Hellweg S. (2016) Spatially Explicit Analysis of Biodiversity Loss due to Global Agriculture, Pasture and Forest Land Use from a Producer and Consumer Perspective, Environmental Science \& Technology 50, 3928-3936, DOI: 10.1021/acs.est.5b06153.

CILSS (2016) Landscapes of West Africa - A Window on a changing world, U.S. Geological Survey, United States.

Curran, M., de Baan, L., De Schryver, A.M., van Zelm, R., Hellweg, S., Koellner, T., Sonnemann, G., Huijbregts, M.A.J. (2011) Toward meaningful endpoints of biodiversity in Life Cycle Assessment. Environmental Science and Technology $45(1), 70-79$.

Curran, M., Maia de Souza, D., Antón, A., Teixeira, R.F.M., Michelsen, O., Vidal-Legaz, B., Sala, S. and Milà i Canals, L. (2016) How well does LCA model land use impacts on biodiversity?-A comparison with approaches from ecology and conservation. Environmental Science \& Technology 50(6), 2782-2795.

de Baan, L., Alkemade, R. and Koellner, T. (2013a) Land use impacts on biodiversity in LCA: a global approach. The International Journal of Life Cycle Assessment 18(6), 1216-1230.

de Baan, L., Curran, M., Rondinini, C., Visconti, P., Hellweg, S. and Koellner, T. (2015) High-resolution assessment of land use impacts on biodiversity in life cycle asessment using species habitat suitability models. Environmental Science \& Technology 49(4), 2237-2244.

de Baan, L., Mutel, C.L., Curran, M., Hellweg, S. and Koellner, T. (2013b) Land use in life cycle assessment: Global characterization factors based on regional and global potential species extinction. Environmental Science \& Technology 47(16), 9281-9290.

Ecoinvent (2016) Ecoinvent V3.3 database, Swiss Centre for Life Cycle Inventories, Dübendorf, Switzerland.

FAO (2016) Mainstreaming ecosystem services and biodiversity into agricultural production and management in East Africa, www.fao.org/3/a-i5603e.pdf 
FAOSTAT (2017) Crop production data 1991-2011, http://www.fao.org/faostat/en/\#data/QC.

Fleishman, E., Noss, R.F. and Noon, B.R. (2006) Utility and limitations of species richness metrics for conservation planning. Ecological Indicators 6(3), 543-553.

IRP (2017). Assessing global resource use: A systems approach to resource efficiency and pollution reduction. Bringezu, S., Ramaswami, A., Schandl, H., O'Brien, M., Pelton, R., Acquatella, J., Ayuk, E., Chiu, A., Flanegin, R., Fry, J., Giljum, S., Hashimoto, S., Hellweg, S., Hosking, K., Hu, Y., Lenzen, M., Lieber, M., Lutter, S., Miatto, A., Singh Nagpure, A., Obersteiner, M., van Oers, L., Pfister, S., Pichler, P., Russell, A., Spini, L., Tanikawa, H., van der Voet, E., Weisz, H., West, J., Wiijkman, A., Zhu, B., Zivy, R. A Report of the International Resource Panel. United Nations Environment Programme. Nairobi, Kenya.

IUCN (2015) Ecosystem profile - Guinean forests of West Africa biodiversity hotspot, www.cepf.net/SiteCollectionDocuments/donor council/CEPF-DC28-8.pdf.

Jeswani, H.K., Burkinshaw, R. and Azapagic, A. (2015) Environmental sustainability issues in the food-energywater nexus: Breakfast cereals and snacks. Sustainable Production and Consumption 2, 17-28.

Kellogg (2013) Kellogg company 2013 fact sheet, http://investor.kelloggs.com/files/doc downloads/Final\%202013\%20Fact\%20Sheet.pdf.

Koellner, T., de Baan, L., Beck, T., Brandão, M., Civit, B., Margni, M., i Canals, L.M., Saad, R., de Souza, D.M. and Müller-Wenk, R. (2013) UNEP-SETAC guideline on global land use impact assessment on biodiversity and ecosystem services in LCA. The International Journal of Life Cycle Assessment 18(6), 1188-1202.

Mendenhall, C.D., Daily, G.C. and Ehrlich, P.R. (2012) Improving estimates of biodiversity loss. Biological Conservation 151(1), 32-34.

Milà i Canals, L., Rigarlsford, G. and Sim, S. (2013) Land use impact assessment of margarine. The International Journal of Life Cycle Assessment 18(6), 1265-1277.

Müller-Wenk, R. and Brandão, M. (2010) Climatic impact of land use in LCA-carbon transfers between vegetation/soil and air. The International Journal of Life Cycle Assessment 15(2), 172-182.

Nemecek T., Bengoa X., Lansche J., Mouron P., Rossi V. \& Humbert S. (2014) Methodological guidelines for the life cycle inventory of agricultural products. Version 2.0, July 2014. World Food LCA Database (WFLDB). Quantis and Agroscope, Lausanne and Zurich, Switzerland.

Nordborg, M., Sasu-Boakye, Y., Cederberg, C. and Berndes, G. (2017) Challenges in developing regionalized characterization factors in land use impact assessment: impacts on ecosystem services in case studies of animal protein production in Sweden. The International Journal of Life Cycle Assessment 22(3), 328-345.

Othoniel, B., Rugani, B., Heijungs, R., Benetto, E. and Withagen, C. (2016) Assessment of Life Cycle Impacts on Ecosystem Services: Promise, Problems, and Prospects. Environmental Science \& Technology 50(3), 10771092.

Saad, R., Koellner, T. and Margni, M. (2013) Land use impacts on freshwater regulation, erosion regulation, and water purification: a spatial approach for a global scale level. The International Journal of Life Cycle Assessment 18(6), 1253-1264.

Statista (2017) Breakfast cereal market in Europe - Statistics and Facts. https://www.statista.com/topics/4205/breakfast-cereal-market-in-europe/

The Scottish Government (2010) Scottish dairy supply chain greenhouse gas emissions, methodology report, http://www.gov.scot/Publications/2011/02/18152808/0.

Thinkstep (2016) GaBi V7.3 software and database.

UNEP-SETAC (2016) Global guidance for life cycle impact assessment indicators, Volume 1, http://www.lifecycleinitiative.org/training-resources/global-guidance-lcia-indicators-v-1/

USDA $(2017) \quad$ Major $\quad$ world crop areas and climate profiles, https://www.usda.gov/oce/weather/pubs/Other/MWCACP/index.htm.

Verones, F., Saner, S., Pfister, S., Baisero, D., Rondinini, C., Hellweg, S. (2013) Effects of consumptive water use on biodiversity in wetlands of international importance. Environmental Science and Technology 47 (21), 12248-12257.

Vidal Legaz, B., Maia De Souza, D., Teixeira, R.F.M., Antón, A., Putman, B. and Sala, S. (2017) Soil quality, properties, and functions in life cycle assessment: an evaluation of models. Journal of Cleaner Production $140,502-515$.

Vijay, V., Pimm, S.L., Jenkins, C.N. and Smith, S.J. (2016) The impacts of oil palm on recent deforestation and biodiversity loss. PLoS ONE 11(7), e0159668.

WRI (2005). Millennium ecosystem assessment: Ecosystems and human well-being: biodiversity synthesis, World Resources Institute, Washington. 


\title{
Accounting for land use, biodiversity and ecosystem services in life cycle assessment: impacts of breakfast cereals
}

\author{
Harish Kumar Jeswani, Stefanie Hellweg and Adisa Azapagic
}

\section{Supporting information}

Table S1 Composition of breakfast cereals (Jeswani et al., 2015)

\begin{tabular}{lr}
\hline \multicolumn{1}{c}{ Ingredients } & $\begin{array}{c}\text { Contribution to the total weight of } \\
\text { ingredients }\end{array}$ \\
\hline Cocoa and chocolate & $4.4 \%$ \\
Corn & $23.1 \%$ \\
Corn flour & $1.8 \%$ \\
Dairy products (milk powder and condensed milk) & $0.6 \%$ \\
Freeze-dried fruits & $0.2 \%$ \\
Fruits and nuts & $1.3 \%$ \\
Honey & $0.3 \%$ \\
Malt & $0.6 \%$ \\
Oats & $2.3 \%$ \\
Oils and fats (including palm oil) & $0.3 \%$ \\
Other ingredients (rice flour, salt, flavours, vitamins, etc.) & $3.2 \%$ \\
Peanuts & $0.4 \%$ \\
Rice (broken and whole) & $20.8 \%$ \\
Sugar & $17.8 \%$ \\
Sweeteners (corn syrup, glucose syrup, fructose syrup, & $2.4 \%$ \\
sorbitol syrup, etc.) & \\
Wheat & $11.4 \%$ \\
Wheat - durum & $1.0 \%$ \\
Wheat gluten & $1.6 \%$ \\
Wheat bran & $3.3 \%$ \\
Wheat flour & $3.0 \%$ \\
Wheat germ & $0.4 \%$ \\
\hline
\end{tabular}

Table S2 Packaging materials (Jeswani et al., 2015)

\begin{tabular}{lc}
\hline Material & $\begin{array}{c}\text { Quantity } \\
\text { (kg/kg product) }\end{array}$ \\
\hline Folding-box board & 0.16 \\
Corrugated board & 0.04 \\
Corrugated pallet layer pads & $2.6 \times 10^{-4}$ \\
High density polyethylene (HDPE) liner & $1.4 \times 10^{-2}$ \\
Stretch wrap (HDPE) & $1.3 \times 10^{-3}$ \\
Pallets & $8.2 \times 10^{-4}$ \\
\hline
\end{tabular}


Table S3 Ecoregion details

\begin{tabular}{|c|c|c|c|}
\hline $\begin{array}{l}\text { Ecoregion } \\
\text { ID }\end{array}$ & Ecozone & Ecoregion & Biome \\
\hline AA0111 & Australasia & $\begin{array}{l}\text { New Britain-New Ireland lowland rain } \\
\text { forests }\end{array}$ & $\begin{array}{l}\text { Tropical and subtropical moist } \\
\text { broadleaf forests }\end{array}$ \\
\hline AA0120 & Australasia & South Eastern Papuan rain forests & $\begin{array}{l}\text { Tropical and subtropical moist } \\
\text { broadleaf forests }\end{array}$ \\
\hline AA0125 & Australasia & Trobriand Islands rain forests & $\begin{array}{l}\text { Tropical and subtropical moist } \\
\text { broadleaf forests }\end{array}$ \\
\hline AA0115 & Australasia & $\begin{array}{l}\text { Northern New Guinea lowland rain and } \\
\text { freshwater swamp forests }\end{array}$ & $\begin{array}{l}\text { Tropical and subtropical moist } \\
\text { broadleaf forests }\end{array}$ \\
\hline AT0111 & Afrotropic & Eastern Guinean forests & $\begin{array}{l}\text { Tropical and subtropical moist } \\
\text { broadleaf forests }\end{array}$ \\
\hline IM0102 & Indomalayan & Borneo lowland rain forests & $\begin{array}{l}\text { Tropical and subtropical moist } \\
\text { broadleaf forests }\end{array}$ \\
\hline IM0107 & Indomalayan & $\begin{array}{l}\text { Chao Phraya freshwater swamp } \\
\text { forests }\end{array}$ & $\begin{array}{l}\text { Tropical and subtropical moist } \\
\text { broadleaf forests }\end{array}$ \\
\hline IM0139 & Indomalayan & $\begin{array}{l}\text { Northern Thailand-Laos moist } \\
\text { deciduous forests }\end{array}$ & $\begin{array}{l}\text { Tropical and subtropical moist } \\
\text { broadleaf forests }\end{array}$ \\
\hline IM0146 & Indomalayan & Peninsular Malaysian rain forests & $\begin{array}{l}\text { Tropical and subtropical moist } \\
\text { broadleaf forests }\end{array}$ \\
\hline IM0158 & Indomalayan & Sumatran lowland rain forests & $\begin{array}{l}\text { Tropical and subtropical moist } \\
\text { broadleaf forests }\end{array}$ \\
\hline IM0160 & Indomalayan & Sumatran peat swamp forests & $\begin{array}{l}\text { Tropical and subtropical moist } \\
\text { broadleaf forests }\end{array}$ \\
\hline IM0163 & Indomalayan & $\begin{array}{l}\text { Tenasserim-South Thailand semi- } \\
\text { evergreen rain forests }\end{array}$ & $\begin{array}{l}\text { Tropical and subtropical moist } \\
\text { broadleaf forests }\end{array}$ \\
\hline IM0165 & Indomalayan & $\begin{array}{l}\text { Tonle Sap-Mekong peat swamp } \\
\text { forests }\end{array}$ & $\begin{array}{l}\text { Tropical and subtropical moist } \\
\text { broadleaf forests }\end{array}$ \\
\hline IM0202 & Indomalayan & Central Indochina dry forests & $\begin{array}{l}\text { Tropical and subtropical dry broadleaf } \\
\text { forests }\end{array}$ \\
\hline NA0801 & Nearctic & California Central Valley grasslands & $\begin{array}{l}\text { Temperate grasslands, savannas, and } \\
\text { shrublands }\end{array}$ \\
\hline NA0803 & Nearctic & $\begin{array}{l}\text { Central and Southern mixed } \\
\text { grasslands }\end{array}$ & $\begin{array}{l}\text { Temperate grasslands, savannas, and } \\
\text { shrublands }\end{array}$ \\
\hline NA0810 & Nearctic & Northern mixed grasslands & $\begin{array}{l}\text { Temperate grasslands, savannas, and } \\
\text { shrublands }\end{array}$ \\
\hline NA0811 & Nearctic & Northern short grasslands & $\begin{array}{l}\text { Temperate grasslands, savannas, and } \\
\text { shrublands }\end{array}$ \\
\hline NA0813 & Nearctic & Palouse grasslands & $\begin{array}{l}\text { Temperate grasslands, savannas, and } \\
\text { shrublands }\end{array}$ \\
\hline NA0815 & Nearctic & Western short grasslands & $\begin{array}{l}\text { Temperate grasslands, savannas, and } \\
\text { shrublands }\end{array}$ \\
\hline NA1309 & Nearctic & Snake-Columbia shrub steppe & Deserts and xeric shrublands \\
\hline NT0101 & Neotropic & Araucaria moist forests & $\begin{array}{l}\text { Tropical and subtropical moist } \\
\text { broadleaf forests }\end{array}$ \\
\hline NT0131 & Neotropic & Jamaican moist forests & $\begin{array}{l}\text { Tropical and subtropical moist } \\
\text { broadleaf forests }\end{array}$ \\
\hline NT0150 & Neotropic & Alto Paraná Atlantic forests & $\begin{array}{l}\text { Tropical and subtropical moist } \\
\text { broadleaf forests }\end{array}$ \\
\hline NT0154 & Neotropic & Petén-Veracruz moist forests & $\begin{array}{l}\text { Tropical and subtropical moist } \\
\text { broadleaf forests }\end{array}$ \\
\hline NT0210 & Neotropic & Arid Chaco & $\begin{array}{l}\text { Tropical and subtropical grasslands, } \\
\text { savannas, and shrublands }\end{array}$ \\
\hline NT0218 & Neotropic & Jamaican dry forests & $\begin{array}{l}\text { Tropical and subtropical dry broadleaf } \\
\text { forests }\end{array}$ \\
\hline NT0704 & Neotropic & Cerrado & $\begin{array}{l}\text { Tropical and subtropical grasslands, } \\
\text { savannas, and shrublands }\end{array}$ \\
\hline NT0801 & Neotropic & Argentine Espinal & $\begin{array}{l}\text { Temperate grasslands, savannas, and } \\
\text { shrublands }\end{array}$ \\
\hline NT0803 & Neotropic & Humid Pampas & $\begin{array}{l}\text { Temperate grasslands, savannas, and } \\
\text { shrublands }\end{array}$ \\
\hline NT1305 & Neotropical & Caribbean shrublands & Deserts and xeric shrublands \\
\hline
\end{tabular}


Table S3 Continued

\begin{tabular}{|c|c|c|c|}
\hline $\begin{array}{l}\text { Ecoregion } \\
\text { ID }\end{array}$ & Ecozone & Ecoregion & Biome \\
\hline OC0105 & Oceania & Fiji tropical moist forests & $\begin{array}{l}\text { Tropical and subtropical moist } \\
\text { broadleaf forests }\end{array}$ \\
\hline OC0201 & Oceania & Fiji tropical dry forests & $\begin{array}{l}\text { Tropical and subtropical dry broadleaf } \\
\text { forests }\end{array}$ \\
\hline PA0402 & Palearctic & Atlantic mixed forests & $\begin{array}{l}\text { Temperate broadleaf and mixed } \\
\text { forests }\end{array}$ \\
\hline PA0404 & Palearctic & Balkan mixed forests & $\begin{array}{l}\text { Temperate broadleaf and mixed } \\
\text { forests }\end{array}$ \\
\hline PA0409 & Palearctic & Celtic broadleaf forests & $\begin{array}{l}\text { Temperate broadleaf and mixed } \\
\text { forests }\end{array}$ \\
\hline PA0412 & Palearctic & Central European mixed forests & $\begin{array}{l}\text { Temperate broadleaf and mixed } \\
\text { forests }\end{array}$ \\
\hline PA0432 & Palearctic & Po Basin mixed forests & $\begin{array}{l}\text { Temperate broadleaf and mixed } \\
\text { forests }\end{array}$ \\
\hline PA0445 & Palearctic & Western European broadleaf forests & $\begin{array}{l}\text { Temperate broadleaf and mixed } \\
\text { forests }\end{array}$ \\
\hline PA0501 & Palearctic & Alps conifer and mixed forests & Temperate coniferous forests \\
\hline PA0904 & Palearctic & Nile Delta flooded savanna & Flooded grasslands and savannas \\
\hline PA1209 & Palearctic & $\begin{array}{l}\text { Iberian sclerophyllous and semi- } \\
\text { deciduous forests }\end{array}$ & $\begin{array}{l}\text { Mediterranean forests, woodlands, and } \\
\text { shrub }\end{array}$ \\
\hline PA1213 & Palearctic & $\begin{array}{l}\text { Mediterranean dry woodlands and } \\
\text { steppe }\end{array}$ & $\begin{array}{l}\text { Mediterranean forests, woodlands, and } \\
\text { shrub }\end{array}$ \\
\hline PA1214 & Palearctic & Mediterranean woodlands and forests & $\begin{array}{l}\text { Mediterranean forests, woodlands, and } \\
\text { shrub }\end{array}$ \\
\hline PA1215 & Palearctic & $\begin{array}{l}\text { Northeastern Spain and Southern } \\
\text { France Mediterranean forests }\end{array}$ & $\begin{array}{l}\text { Mediterranean forests, woodlands, and } \\
\text { shrub }\end{array}$ \\
\hline PA1216 & Palearctic & Northwest lberian montane forests & $\begin{array}{l}\text { Mediterranean forests, woodlands, and } \\
\text { shrub }\end{array}$ \\
\hline PA1221 & Palearctic & $\begin{array}{l}\text { Southwest lberian Mediterranean } \\
\text { sclerophyllous and mixed forests }\end{array}$ & $\begin{array}{l}\text { Mediterranean forests, woodlands, and } \\
\text { shrub }\end{array}$ \\
\hline
\end{tabular}

\section{Reference}

Jeswani, H.K., Burkinshaw, R. and Azapagic, A. (2015) Environmental sustainability issues in the food-energy-water nexus: Breakfast cereals and snacks. Sustainable Production and Consumption 2, 17-28. 